\title{
Reaching Out to the West: An Assessment of Chinese Students' Views Regarding Foreign-Delivered University Programs in China
}

\author{
MIKE WILLIS \\ Department of Marketing, University of Ballarat, Ballarat, Victoria, Australia
}

This article identifies the views and expectations of Chinese students located in nine cities in China and Hong Kong in regard to the delivery of foreign degree programs within China. This delivery mode is becoming a common form of educational delivery and augments other modes of international activity such as study abroad and distance education. The research has found that students wanted a relatively unadapted course, delivered in English by foreign academics, with a high level of academic and administrative servicing in China. They did not like subjects which had been overly adapted for the Chinese market, since these were viewed to be somewhat lacking in authenticity. However, some very minor areas of adaptation were required to meet some specific local requirements, but in essence students wanted courses which were a close replication of what it would be like to study in the foreign university location, whether it be in America, Australia, or Europe. The value of this research is that it identifies the desire of students for relatively unadapted foreign programs in China. This finding is of use to foreign universities planning courses and programs in China and also adds to the debate about the adaptation or standardization of services in a Chinese context.

KEYWORDS China education, student experience

Submitted: October 2008; revised: May 2009; accepted: December 2009.

Address correspondence to Mike Willis, University of Ballarat, 37 King Street South, Ballarat, Victoria 3350, Australia. E-mail: m.willis@ballarat.edu.au 


\section{INTRODUCTION}

China has one of the largest higher education systems in the world with over 1088 universities and 918 institutes of higher education, the bulk of which have alliances with foreign universities for a range of activities including the delivery of degree and postgraduate degree programs in China for Chinese and foreign students.

Although various aspects of these alliances have been studied, for example, by Hayhoe (1996) and Willis (2000), there has been less attention paid to the delivery of foreign-sourced courses and programs within China. In 2001, Willis and Rushdi (2005) conducted some basic and initial research into this issue. The current research aims to expand on this research by including a far wider range of Chinese cities (including Hong Kong). The research also uses a combination of quantitative and qualitative (depth interview) techniques to gain a deeper insight into students' perceptions and expectations regarding the delivery of foreign programs within their own country. The earlier research was somewhat limited in that it used a questionnaire and did not encompass depth interviews which might have added to the raw data collected in the questionnaire. The value of the current research is that it aims to delve deeper into the issue of foreign educational delivery in China, which is an area of considerable growth and demand.

\section{LITERATURE REVIEW}

There are a large number of studies considering the issue of study abroad and distance education, although there are very few on the specific issue relating to the development and delivery of programs within the host country, such as China. The various studies on study abroad and distance education are of validity in the context of the present article because they identify matters which may be relevant for in-country program delivery, such as cultural and teaching issues facing foreign universities. Key studies on the concept of study abroad by Austin (1988), Hausler, Sharma, and Sivagnanam (1995), Molla and Sedlacek (1989), Wu (1989), Bromilow and Zubrzycki (1990), James, Baldwin, and McInnes, (1999), Steadman and Dagwell (1990), Stewart and Felicetti (1991), Lawley (1993), Lawley and Blight (1995), Wilkinson (1995), Rao, (1979), Ridings and Pokarier (1998), and Lawley and Perry (1998) identified a range of factors of importance to overseas students when considering which foreign university and country within which to undertake their study. These included the ranking, status and image of the foreign university, the range of courses available, the influence of friends and peers in the selection of a foreign university, the image of the foreign country, and financial issues. Some of these issues might also be relevant to the students' 
views about foreign university delivery within their home country, such as the issue of image and status of the university.

In regard to research on distance education, studies tended to consider many of the same issues as above, but also focused on other salient aspects, such as the modes of educational delivery, the country source of student enrolments, the use of technology, and the concept of multi-modal delivery (whereby, for example, a course may be delivered to a student market via a range of modes, including distance education, augmented distance educationwhere staff may fly to the foreign country to deliver a range of courses to support distance programs - and study abroad; Cookson, Donaldson, \& Quigley, 1990; Edwards, 1997; Jones, O'Shea, \&d Scanlon, 1987). Again, issues of culture, reputation of the foreign university, costs, and range of units available are raised in this literature but not in a way which is directly applicable to "in-country" delivery. However, this literature does help to provide a general framework into which specific "in-country" issues can be considered.

More specific research on the actual delivery of foreign source educational programs within the host country has been undertaken by Hayhoe (1989, 1996) and to a lesser extent by Street (1992), Kretschmer (1994), and at the secondary (or middle) school level by Ross (1993). These studies identified some issues of relevance to the specific delivery of courses and programs in China. These were the need to adapt courses and programs in often quite subtle ways to meet Chinese students' learning needs; the importance of using English as well as Chinese in teaching situations; the desire of students to access Western business and management courses and programs so as to play their part in the emerging market economy of China; and the sheer complexity of attempting to deliver Western concepts, ideas, and even values, to a Chinese audience coming from a very different cultural background. Hayhoe (1989, 1996) focused on structural aspects of collaboration-that is, how the two sides organized and managed their alliances so that beneficial exchanges of information and resources could take place. Her various studies are among the most balanced and considered undertaken to date.

Chinese authors (Jiang, 1998; Ji, 1998; Jing, 1995; Ju, 1997a, 1997b; Liu, 1995a,, 1995b; Luo \& Wu, 1995; Lu, 1994; Yanshen, 1997; Xu, 1991; Xu, 1998) also considered foreign "in-country" delivery of courses and programs and reflect many of the issues raised by Hayhoe (1996). They identified a range of course gaps which were often filled through foreign cooperationparticularly in business, management, and marketing, and also to a lesser extent in engineering, the sciences, and other more traditional fields. However, the major area of demand was generally if not always for the earlier group of subjects because they were seen to be more relevant to the development of a market economy in China. These authors also indicated that the major means of entering the China market for the delivery of courses and programs 
was via the state education sector, although there was increasing scope for entry via private universities, institutes, and agents, especially in Shanghai. This group of writers also reflected the government desire for an increase in the range of postgraduate courses and programs to raise the standard of the highest level of the higher education system-again often achieved through foreign cooperation. However, the views of prospective students were not tested by any of the above authors who tended to discuss institutional issues vis-à-vis modernization and foreign alliance cooperation.

Other more general studies of the higher education system in China, particularly those which discussed its changing role vis-à-vis the modernization of China, tended to identify a range of reasons why Chinese universities were keen to collaborate with foreign universities in regard to the development and delivery of courses and programs in China and abroad. This modernization could be achieved, in part, through foreign collaboration. Again, however, these studies, while of value in illustrating the various structural factors driving educational change and cooperation with foreign universities, did not specifically deal with Chinese students' views.

Another area of the literature that has some relevance to this study is the issue of adaptation and standardization of services in an international marketing context. In a Chinese educational market entry context, this issue relates to the question of whether subjects and teaching delivery styles need to be adapted when delivered in a foreign country. Street (1992), Hayhoe (1996), Kretschmer (1994), Ming (1999), and Ross (1993) indicated that adaptation was required, although sometimes the Chinese university or school requested a Western-style course or delivery approach (that is, a standardized approach where the foreigners would teach as if at home). On the whole, however, some level of adaptation was still required to meet the needs of students accustomed to a more regimented and structured teaching approach (Ross).

In a wider marketing context, there is much research on adaptation versus standardization, with many researchers arguing that a product or service should be adapted in varying degrees depending on the nature of the market (Hite \& Fraser, 1988; Larsen, Mehta, \& Rosenbloom, 1997). These authors argued that there is a continuum between standardization and adaptation - that is, varying levels of adaptation depending on the nature of the market. This view tends to mirror that of the educational researchers referenced above who noted that adaptation was required but often to quite complex varying levels of degree. Others have focused more on the factors that affect the level and degree of adaptation or standardization (Douglas \& Wind, 1987). Based on the work of these authors and in particular, Hayhoe (1996) and Street (1992), it would appear that at least some level and form of adaptation would be required to deliver a course in China.

The specific issue of students' perceptions, expectations, and views of foreign university-delivered programs within China was tested by Willis and 
Rushdi (2005) who identified the desire, on the part of Chinese students, for a foreign taught, English language, relatively unadapted program. However, this data was gathered in a survey questionnaire, and there was little discussion of what students really felt about foreign programs in regard to these initial and, to a large extent, exploratory findings. For example, they wanted a program which was as close as possible to that provided in the foreign university home campus-but exactly how close? Were they really aware of what study in a foreign university was like?

From this review, it can be seen that the existing research on study abroad and distance education does identify certain issues that may be of relevance to students when choosing to undertake a foreign-provided program in their home country. For example, study abroad and distance education students were concerned about the image of the foreign university, the range of programs available (particularly in business and management fields), the cost of the program, and the range of services-all issues which might also be of relevance if they chose to study for a foreign program at home in China. The literature focusing on the modernization of the Chinese education system (Pepper, 1994, 1996) tends to identify a range of underlying reasons why Chinese universities have sought to secure foreign university partners, but does not as a rule consider student views, but it is of relevance because some of these reasons, such as the desire of universities to play a stronger role in economic modernization and internationalization might also be relevant for students when choosing to study in a foreign university in China. The various and somewhat more relevant studies of foreign educational delivery within China, such as those undertaken by Ross (1993) and Hayhoe (1996), have tended to focus on teaching issues and structural aspects of alliance activity without quite identifying the views of students. There remains a dearth of studies about students' perceptions and views about the delivery of foreign programs within China apart from work undertaken by Willis and Rushdi (2005) which is limited, exploratory, and quantitative in nature. Research into the issue of adaptation versus standardization casts a useful light on the present research topic as it raises the issue of how much educational programs should be adapted in a market such as China.

\section{METHODOLOGY}

Data was collected from 296 Chinese 1st-year university students located in Nanjing, Hong Kong, Dalian, Beijing, Wuhan, Shanghai, Tianjin, Dongguan, and Huangzhou. A summary of the data is included in Table 1 at the end of this article. The respondents from the various mainland Chinese cities responded to the various questions in a very similar manner, so this data is summarized in the first column. However, the data from Hong Kong showed some minor differences so this is included as a separate column in 
TABLE 1 Comparison of Students' Expectations and Views Regarding "In-Country" Delivery of Education Programs-China and Hong Kong

\begin{tabular}{|c|c|c|c|c|c|c|c|}
\hline & \multirow[b]{2}{*}{ Variables } & \multicolumn{3}{|c|}{ China (sample size 206) } & \multicolumn{3}{|c|}{$\begin{array}{c}\text { Hong Kong } \\
\text { (sample size 90) }\end{array}$} \\
\hline & & Mean & $S D$ & $t$ values & Mean & $S D$ & $t$ values \\
\hline 1 & Reputation of university & 4.65 & .60 & $39.21^{* * * *}$ & 4.56 & .58 & $25.32^{* * * *}$ \\
\hline 2 & Range of subjects & 4.44 & .60 & $34.65^{* * * *}$ & 4.44 & .60 & $22.42^{* * * *}$ \\
\hline 3 & Delivery in English & 4.62 & .58 & $39.66^{* * * *}$ & 4.06 & .84 & $11.87^{* * * *}$ \\
\hline 4 & Delivery in Chinese & 3.00 & .93 & .00 & 2.70 & .94 & $-3.02^{* * *}$ \\
\hline 5 & Delivery in both languages & 3.31 & .88 & $5.01^{* * * *}$ & 2.90 & .97 & -.98 \\
\hline 6 & Up-to-date materials & 4.53 & .62 & $35.51^{* * * *}$ & 4.27 & .72 & $16.79^{* * * *}$ \\
\hline 7 & Up-to-date technology & 4.60 & .55 & $41.21^{* * * *}$ & 4.19 & .79 & $14.25^{* * * *}$ \\
\hline 8 & Foreign teachers & 4.66 & .62 & $38.57^{* * *}$ & 4.09 & .86 & $12.06^{* * * *}$ \\
\hline 9 & Chinese teachers & 3.02 & .81 & .35 & 2.84 & 1.00 & -1.47 \\
\hline 10 & Business subjects & 4.35 & .85 & $22.74^{* * * *}$ & 4.19 & .75 & $15.08^{* * * *}$ \\
\hline 11 & Management subjects & 4.35 & .86 & $22.43^{* * * *}$ & 4.18 & .76 & $14.74^{* * *}$ \\
\hline 12 & Marketing subjects & 4.35 & .84 & $23.00^{* * * *}$ & 4.10 & .77 & $13.64^{* * *}$ \\
\hline 13 & Information technology subjects & 4.37 & .84 & $23.15^{* * * *}$ & 4.09 & .80 & $12.88^{* * * *}$ \\
\hline 14 & Economics subjects & 4.21 & .88 & $19.68^{* * * *}$ & 3.72 & .94 & $7.32^{* * * * 4}$ \\
\hline 15 & Science subjects & 3.20 & .73 & $3.92^{* * * *}$ & 2.88 & .95 & -1.23 \\
\hline 16 & Engineering subjects & 3.19 & .73 & $3.72 * * *$ & 2.83 & 1.04 & -1.54 \\
\hline 17 & Technology subjects & 3.22 & .73 & $4.22^{* * * *}$ & 3.19 & 1.10 & $1.64^{*}$ \\
\hline 18 & Medical subjects & 3.12 & .76 & $2.30^{* *}$ & 2.67 & .91 & $-3.47^{* * * *}$ \\
\hline 19 & Agriculture subjects & 2.99 & .71 & -.20 & 2.48 & .92 & $-5.31^{* * *}$ \\
\hline 20 & Access to study abroad & 4.05 & .78 & $19.19^{* * * *}$ & 3.05 & 1.31 & .32 \\
\hline 21 & Delivery via Chinese university & 3.74 & .88 & $11.86^{* * * *}$ & 4.23 & .72 & $16.26^{* * * *}$ \\
\hline 22 & Delivery via agent & & & & 2.97 & 1.12 & -.28 \\
\hline 23 & Subjects delivered in home city & 3.83 & .98 & $12.14^{* * * *}$ & 4.04 & .90 & $11.03^{* * * *}$ \\
\hline 24 & Including theories & 3.84 & .71 & $16.74^{* * * *}$ & 3.40 & .88 & $4.29^{* * * *}$ \\
\hline 25 & Including practical aspects & 4.06 & .72 & $20.92^{* * * *}$ & 4.00 & .71 & $13.34^{* * * *}$ \\
\hline 26 & MBA program & 4.45 & .75 & $27.62^{* * * *}$ & 3.91 & .86 & $10.10^{* * * *}$ \\
\hline 27 & DBA program & 3.41 & .82 & $7.15^{* * * *}$ & 3.21 & .95 & $2.13^{* * *}$ \\
\hline 28 & PhD program & 3.81 & .94 & $12.38^{* * * *}$ & 3.17 & .94 & $1.68^{*}$ \\
\hline 29 & $\begin{array}{l}\text { Studying in home country: } \\
\text { is not good }\end{array}$ & 2.4 & .98 & -1.9 & 2.60 & 1.14 & \\
\hline 30 & is $g$ & 3.82 & .69 & $16.72^{* * * *}$ & 3.61 & .67 & $8.61^{\text {***: }}$ \\
\hline 31 & would be acceptable & 3.72 & .69 & $14.69^{* * * *}$ & 3.64 & .59 & $10.11^{\text {**** }}$ \\
\hline 32 & would be more practical & 3.74 & .75 & $13.86^{* * * * *}$ & 3.80 & .83 & $8.96^{* * * *}$ \\
\hline 33 & would be cheaper & 3.27 & 1.09 & $3.51^{* * *}$ & 3.63 & .97 & $6.02^{* * * *}$ \\
\hline 34 & would let more people stud & 3.91 & .61 & $20.94^{* * * *}$ & 3.41 & .87 & $4.43^{\text {***: }}$ \\
\hline 35 & I would rather still study abroad & 4.16 & .82 & $19.96^{* * * *}$ & 2.91 & 1.17 & -.73 \\
\hline
\end{tabular}

Note. Significance level: ${ }^{* * * *} p \leq .01,{ }^{* *} p \leq .05,{ }^{*} p \leq .10$.

Table 1. The data resulted from a questionnaire which asked the students to consider the same issues as researched by the authors in 2001. The survey instrument was in English as all subjects were competent in that language.

In addition, qualitative depth interviews were then held with students in various cities (Nanjing, $n=18$; Hong Kong, $n=42$; Dalian, $n=6$; Beijing, $n=12$; Wuhan, $n=5$; Shanghai, $n=16$; Tianjin, $n=12$; Dongguan, $n=14$; Huangzhou, $n=12$ ) to amplify their answers to the various quantitative 
questions and explore issues in more detail. Students were asked to comment on the use of foreign teachers, the range of units they wanted, the use of language, postgraduate options and views, and delivery modes. They were also asked to comment on the degree of adaptation or standardization required and were asked some broad questions about why they wanted to study for a foreign program in China, rather than abroad, and in preference to a Chinese university education.

Data gathered via the survey instrument were inputted using SPSS (Statistical Package for Social Sciences) Version 10. All variables were tested for normality by using the standard errors of skewness and kurtosis (Tabachnick \& Fidell, 1989). Some of the variables depicted a distribution pattern, which departed from normality. However, the departures from normality were not severe. The statistical procedure used in this analysis is "one sample $t$ test." It should be noted that this test is fairly robust to mild variations from normality if the number of observations are not too small (Devore \& Peck, 1993). The null hypothesis of "the factors were neutral" (neither important nor unimportant) was tested for questions relating to students' expectations and views, and the null hypothesis "I neither agree nor disagree with the view" was tested for questions relating to the comparison of "in-country" study to study abroad using a test value of 3 . The results of the statistical analysis for the sample from China and from Hong Kong are presented in Table 1.

\section{DISCUSSION AND ANALYSIS}

Based on quantitative data supported by depth interviews, some of the key findings were as follows (when the phrase "both locations" is used, it is referring to the various mainland cities, and Hong Kong):

The reputation of the foreign university was of prime importance in all locations. Universities such as Harvard, Stanford, and Johns Hopkins were viewed as being of particularly high status and reputation.

Students in both locations felt that the reputation of the foreign university was important for several reasons:

- to impress their family and friends (an issue of status, image, and prestige);

- to improve their chances of obtaining better paid jobs.

They also associated the ranking and status of foreign universities with the perceived level and quality of teaching.

There was a deeply ingrained belief in both locations, but more so in mainland China, that some of the best known universities in the world, such as Stanford and Harvard, were the repositories of knowledge and skills which were essential to the future of the students. Chinese mainland students 
believed that these famous universities would give them the skills needed to play a key role in the development of a modern Chinese market economy. Hong Kong students believed that the status of these universities would almost guarantee a successful career in Hong Kong, or elsewhere. In both cases, students felt that rank and the status of the universities was of pivotal importance to them when selecting a foreign course for study in China/ Hong Kong. Hong Kong students discussed this issue in directly personal terms; Chinese students had a wider view, related to national economic development goals, in addition to their own personal aims and objectives.

The range of subjects offered by the foreign university, in China or Hong Kong, was also important, particularly in regard to subjects which:

- encompassed business, management, and international aspects which were relevant to the development of a market economy in (mainland) China and the needs of the job market (Hong Kong);

- provided students, in both locations, with an experience of being taught in a Western (non-Chinese style) with its perceived emphasis on creativity, individualism, dynamism, and problem solving; and

- were able to deliver the above aspects of education in a way that was understandable to Chinese students. This was done when foreign universities were able to deliver Western concepts and ways of learning in a manner that encompassed some degree of adaptation to meet Chinese learning styles which tended to be based more on group learning and rote processes.

Subjects outside the axiom of business-management, such as in the sciences, were not of much interest since they were not particularly associated with the "West." As one student noted, Chinese universities were very good at science, engineering, and many of these types of areas - the value of a foreign university program was its excellence in business and management fields.

Delivery in English was important in both locations and particularly in mainland China, although it was also important in Hong Kong. Students believed that English as the language of instruction was important for several reasons:

- English language instruction was felt to be a sign that the course was "authentic" and equivalent to what would be received by the students if they were to study in the foreign university home campus;

- the use of English language was viewed as being part of the process of accessing Western values, ideas, and cultural messages-students viewed language as a type of conduit to the West; and

- by studying in English, students in both locations could improve their job chances, in mainland China because of the opening of China to the world under the WTO (World Trade Organization); and in Hong Kong because English was so often the language of international business. 
If classes were delivered in Chinese, students felt that they were not authentic, and were too much like classes delivered by local universities. For these reasons, delivery in Chinese was not particularly liked, although students did warm to the idea of having classes delivered in English and Chinese as a backup. However, it was essential to the students that English was the prime language of instruction, as this was viewed as being "the real thing," as noted by students in discussions. Similarly, there was a marked preference for foreign rather than Chinese teachers as the latter could easily be accessed (at far less cost) through local universities. However, students did like some degree of access to Chinese teachers to help clarify issues raised by foreign teachers. An ideal situation for students was where the majority of the classes were delivered in English, by foreigners, with some background support and assistance provided by the local teachers. This was the view from all locations, although just a little less so in Hong Kong where local universities (and their teachers) rated so highly.

The use of up-to-date materials and technology rated quite strongly, but the depth interviews indicated that this issue was of far less importance than the types of units offered (business and management), access to foreign teachers, and delivery in English. Indeed, it was very important to the students that they received international textbooks (not based on China or Hong Kong which they felt were too local) but also not based on the foreign location such as the United States or Australia. They wanted international case studies, texts, and programs which they associated with a standardized unadapted university program delivered by a foreign university in its other global and home campuses. They despised material which included local assignments which they viewed as patronizing and not indicative of what they would receive if they studied in the foreign university home (and usually main) campus. They also indicated their dislike of web-based course delivery which they believed was tedious, expensive to download (for example, to print PDF files), and singularly lacking in any form of human contact. This did not constitute-to them-any possible form of "foreign delivery" in China, but rather, a computer-based export of education which was not desirable from their point of view. They wanted foreigners in the classroom, in China.

As noted in Table 1, there was a marked preference for business and management units and far less for traditional units. This was so for both locations, but even more so for mainland Chinese students than for Hong Kong respondents, where the response was less extreme although still marked. Specific units requested were in international business and marketing, accounting, management, project management, innovation, differentiation, problem solving, strategy, competitive analysis, economics, business law, and banking. Students felt that China (and Hong Kong) were adept in the sciences and other fields, such as medicine: it was in the business field that many students felt that foreign universities still had a certain edge. 
Access to study abroad programs was also tested and rated quite well in mainland China and a little less so in Hong Kong. Students felt that they at least wanted the chance to study abroad at some future stage in their degree program. They admitted that this might not be a viable option because of family, job, and financial reasons, but they still liked the idea of being able to choose as they worked their way through their degree program. However, they said that they would not choose a program just because it offered the chance to study abroad-of far more importance was to select a China-based program which was perceived to be properly resourced, supported, and taught.

Delivery via a Chinese university was one of the more interesting findings since it was considered quite important in China itself, and even more so in Hong Kong, even though in that location, foreign universities could deliver their programs through agents, colleges, and institutes. In mainland China it was usually common for foreign universities to deliver their programs through Chinese universities and there were fewer entry options available outside a few locations such as Shanghai. Chinese mainland students felt that delivery via a Chinese university was important because the program could be monitored, controlled, and maintained at a satisfactory level (by the Chinese university). Hong Kong university students felt that the key reasons of delivering overseas programs via a local university included maintenance of brand image and equity, and also to guarantee their ongoing access to library, administrative, and some local academic support. In fact, this synergy between the two university partners was seen by students to deliver them a product of a quality that would be unachievable by each university as a separate entity. Mainland students felt that the key reasons related to quality control, whereas in Hong Kong, the view was more pragmatic - they felt that this process would guarantee them better facilities.

Delivery via an agent was not directly in China (since the use of agents was not very common outside of Shanghai and Beijing), but it was raised in Hong Kong where students indicated that they preferred delivery via a recognized Hong Kong university partner, for reasons of status and also to access university services such as library facilities.

A question was then asked as to whether the students felt it was important that a wide range of foreign-sourced units were delivered in their home city-such as some of the smaller cities in China rather than just Shanghai or Beijing; or in the case of Hong Kong, in the New Territories in addition to areas such as Kowloon or Hong Kong Island. This was considered to be an important issue in both locations: students wanted greater flexibility of delivery whereby foreign universities, and their local partners, delivered more units in more locations in both Hong Kong and China. Too many universities, they felt, just choose to focus on one key city/location, to which the students were expected to travel. This was quite bitterly resented 
in both locations. This was indicative of a view, expressed in both locations, that foreign universities too often delivered small scale, and poorly serviced, "in-country" degree programs just to "make money."

The issue of theory versus practice in the context of subjects or units was also tested and students wanted both (although the quantitative data does not adequately convey what students expressed in the qualitative depth interviews), as what they actually wanted was access to Western concepts, ways of thinking, and techniques delivered in a way that was not too difficult for them-in other words, a foreign teaching style modified only to the extent that it was required to meet the learning needs of the Chinese students. However, particularly in mainland locations, students felt that foreign teachers often failed to deliver this Western style of teaching in a way that was able to be absorbed by students accustomed to a somewhat more rigid and group-based Chinese style. They recognized that it took a considerable degree of skill to be able to teach in a Western style (which they wanted), with just enough modification to suit local cultural needswithout going too far.

One of the more unusual aspects and issues emerging from this research was students' perceptions of studying for a higher foreign university degree-remembering that the data collected was from undergraduate students.

Chinese mainland students were very keen on postgraduate study, however, Hong Kong students were rather less interested; they wanted an undergraduate degree to improve their job prospects. Mainland students wanted to continue their studies for reasons of prestige and perceived value to themselves when applying for a job. In a sense they felt that they had more time than Hong Kong students who felt that they were often scrambling just to complete their undergraduate degree in what was a very competitive market.

Of the remaining issues, one was of particular importance, and this was the last question which asked the students whether they would still rather study abroad. Chinese students still wanted to study overseas; Hong Kong students were not so interested. Again, this related to issues of time and perceived job market situations: Hong Kong students just wanted to successfully complete their degree program and get a better job (or retain their existing position); Chinese students felt that a stint of overseas study would enable them to better understand the international world in which China desired to play an increasingly active role.

\section{SUMMARY}

Students in all locations wanted an unadapted, internationalized, foreigndelivered, English language program that focused on a range of business 
and management units with an international perspective. They also wanted the teaching style to be international with just a little local adaptation to suit their sensibilities. Chinese students viewed these programs as being a window on the West and a way of improving their job opportunities; Hong Kong students felt that these programs were linked to obtaining a better job. To the Chinese mainland students, delivery via a Chinese university was a way of exerting control and ensuring brand image and service quality; to the Hong Kong students it was a means of accessing better local facilities and equipment. Agents were not liked in Hong Kong; in China they were considered not relevant to this research issue. However, and in general, the differences between students in Hong Kong and the rest of China were marginal. The former were perhaps a little more pragmatic and job related in terms of their responses to the various issues raised in this research; the latter were a little more idealistic and generalized in their responses to the various issues.

Some additional issues and comments were raised by respondents in depth interviews and these were as follows:

- Students wanted the foreign university to provide full-time foreign academic and administrative staff on campus in China as a way of ensuring a quality service and they did not like the typical situation where foreign staff flew in and out of China for short periods of time.

- Students felt that a joint venture in which the two sides established a separate building complex (including offices, libraries, accommodation, and teaching areas) was far better than making use of Chinese university facilities in a haphazard way-again, this issue was associated with quality and service standards.

- Students detested programs which were only partly delivered in China with the remaining units made available via study abroad within the foreign country (such as Australia or Canada) or via distance education. They wanted to be able to study at least all of the core degree units in China, although they liked the option of being able to study abroad if and when the opportunity arose. However, they believed that this should be an option, and not a requirement because the foreign university provided an inadequate and incomplete level of service within China.

- Students wanted, but rarely obtained (apart from a few very well-developed alliance programs), subjects delivered as follows: in an unadapted way as regards content and even large parts of the foreign teaching style, but with what could be termed a transfer component in each unit, whereby students were taught how to transfer their new "Western" learning into their own local environment. This could be included as part of assignment work. They believed that too often they were not assisted in learning how to transfer their new Western skills and ways of thinking into their local workplace. Students in the mainland expressed this view more than their 
counterparts in Hong Kong. This is an issue which requires more research. Even though this issue was of importance, it did not affect the views of the students that they still wanted a primarily unadapted course delivered to them in China. The "transfer" issue was considered to be an issue of implementation, not of course structure, content, and delivery.

- Students treated in-country delivery of a foreign university program as a quite separate mode and form of educational delivery from study broad or distance education, even though many foreign universities tended to link them together as part of their international educational offerings. Similarly, they viewed distance education programs as being another mode as well. They liked, and wanted, a complete foreign degree or postgraduate degree program to be available in China: this was by far their preferred option. Other distance modes were treated as an exercise on cost cutting.

- Almost all students felt that foreign universities failed to provide a comprehensive, committed, and quality service in China or Hong Kong, and they felt that the foreign programs they attended were generally second rate compared to equivalent programs available in the foreign university home campus. However, there were some exceptions such as the Nanjing University, Johns Hopkins Centre for American Studies which had full-time American and Chinese academic and teaching staff and its own facilities including a well-stocked library.

The research also indicates that many of the existing programs which involve foreign staff flying in and out of China for short periods of compressed teaching may be doomed in the long term since it was evident that this was not what the Chinese or Hong Kong students wanted. Even when they chose to study part time, they still wanted access to full-time foreign academic and administrative staff in China. Furthermore, programs which were administrated from the overseas campus (for example, from Australia) may also be questionable, since again, students wanted administrators in their home markets. In essence, this research indicates a maturing Chinese higher education market in which students were only too aware of what they wanted and what were some of the problems and issues facing foreigndelivered programs in Hong Kong and the rest of China. Lastly, foreign universities still need to access China via high ranking Hong Kong or Chinese universities as this was viewed as a way of ensuring service and branding quality in all locations.

\section{REFERENCES}

Austin, M. (1988). Asian electrical and computer engineers at a California University: Why are they here? Why might they stay? Santa Barbara: University of California Press. 
Bromilow, G., \& Zubrzycki, J. (1990). Our education services go to market. Australia Now, 14(1), 25-27.

Cookson, P., Donaldson, D., \& Quigley, P. (1990). Contemporary issues in American distance education. New York: Pergamon Press.

Devore, J., \& Peck, R. (1993). Statistics: The exploration and analysis of data. Pacific Grove, CA: Duxbury Press.

Douglas, S., \& Wind, Y. (1987). The myth of globalization. Columbia Journal of World Business, 12(2), 19-29.

Edwards, R. (1997). Changing places: Flexibility, lifelong learning, and a learning society. New York: Routledge.

Hausler, T., Sharma, R., \& Sivagnanam, T. (1995). Australian university experiences of fee-paying overseas students. Melbourne, Australia: Swinburne University of Technology Press.

Hayhoe, R. (1989). China's universities and the open door. New York: M. E. Sharpe, Inc.

Hayhoe, R. (1996). China's universities, 1895-1995: A century of cultural conflict. New York: Garland Publishing.

Hite, R., \& Fraser, C. (1988). International advertising strategies of multinational corporations. Journal of Advertising Research, 28, 9-17.

James, R., Baldwin, G., \& McInnes, C. (1999). Which university: The factors influencing the choices of prospective undergraduates, evaluations and investigations programme. Canberra, Australia: Higher Education Division, Department of Education, Training and Youth Affairs.

Ji, J. (1998). Moving the reform of the higher education system into greater depths enthusiastically and steadily. Chinese Education and Society, 31(6), 5-28.

Jiang, N. (1998). How will higher education reach another plateau in 1997? Chinese Education and Society, 31(6), 47-51.

Jing, Y. (1995). Who will be teaching our students tomorrow? Chinese Education and Society, 28(5), 9-27.

Jones, A., O'Shea, T., \& Scanlon, E. (1987). The computer revolution in education: New technologies in distance education teaching. New York: St. Martins Press.

Ju, C. (1997a, September 5). Education reform still a long way to go in China. China Daily, p. 3.

Ju, C. (1997b, September 4). Quality oriented education to speed up. China Daily, p. 4.

Kretschmer, F. (1994). An American in China, coping with cultures. Westport, CT: Bergin \& Garvery.

Larsen, T., Mehta, R., \& Rosenbloom, B. (1997). Global marketing channels and the standardization controversy. Journal of Global Marketing, 11(1): 49-64.

Lawley, M. (1993). Factors influencing the choice of destination in international education: The case of Hong Kong. Unpublished master's thesis, University of Southern Queensland, Australia.

Lawley, M., \& Blight, D. (1995, September). International students: Reason for choice of an overseas destination. Paper presented at the 11th Annual International Education Conference, Melbourne, Australia.

Lawley, M., \& Perry, C. (1998). Thai \& Malaysian students'perceptions of overseas study destinations: An exploratory study. Toowoomba, Australia: University of Southern Queensland, Department of Marketing. 
Liu, R. (1995a). Combining tracks for publicly funded students and self supported students. Chinese Education and Society, 28(4), 22-50.

Liu, R. (1995b). College and universities admissions: The rate of growth must be appropriate. Chinese Education and Society, 28(6), 50-65.

Lu, J. (1994, August). Educational research in China: Capacities and achievements. Paper presented at the 4th International Conference on Chinese Education in the 21st Century, Shanghai, China.

Luo, W., \& Wu, W. (1995). Heavy laden wings: Sad contemplations on China's education. Chinese Education and Society, 28(1-2), 20-35.

Ming, S. (1999). Perceptions of the place of expatriate English language teachers in China. Unpublished doctoral dissertation, Latrobe University, Melbourne, Victoria, Australia.

Molla, B., \& Sedlacek, W. (1989). International student self-appraisal and institutional expectations (Research Rep. No. 23-89). College Park: University of Maryland, Counseling Center.

Pepper, S. (1994). Regaining the initiative for education reform and development. In L. C. Kin, S. Pepper, \& T. K. Yuen (Eds.), China Review 1995. Hong Kong: The Chinese University of Hong Kong Press.

Pepper, S. (1996). Radicalism and education reform in 20th-century China: The search for an ideal development model. London: Cambridge University Press.

Rao, G. (1979). Brain drain and foreign students - A study of the attitudes and intentions of foreign students in Australia, the USA, Canada and France. Brisbane, Australia: University of Queensland Press.

Ridings, S, \& Pokarier, C. (1998). Dreaming spires or dreary spivs: Reputation in marketing Australian education abroad. Brisbane, Australia: Queensland University of Technology, School of Marketing and International Business.

Ross, H. (1993). China learns English: Language teaching and social change in the people's republic. New Haven, CT: Yale University Press.

Steadman, G., \& Dagwell, R. (1990). A survey of overseas students in Queensland. Australian Universities Review, 1-2, 59-63.

Stewart, K., \& Felicetti, L. (1991). Marketing a public university to international students. Journal of Professional Services Marketing, 7(1), 67-74.

Street, N. (1992). In search of Red Buddha. New York: Peter Lang.

Tabachnick, B. G., \& Fidell, L. S. (1989). Using multivariate Statistics. New York: Harper and Row.

Wilkinson, J. (1995). Marketing Australian universities to overseas students. AsiaAustralia Marketing Journal, 1, 71-78.

Willis, M. (2000.) How Chinese state universities and foreign universities cooperate in an international education market: The development and application of a four tiered Sino-foreign higher education cooperation model. Paper presented at the Australian and New Zealand Marketing Academy Conference 2000, Griffith University, Gold Coast, Queensland, Australia.

Willis, M., \& Rushdi, M. (2001). An identification and analysis of students' expectations and views regarding foreign-sourced tertiary education programs delivered in China: Investigating the next stage of internationalisation and market entry for foreign universities. Journal of Marketing for Higher Education, 15(2), 1-30. 
Wu, W. C. (1989). Strategy formulation in the international services sector: Factors influencing students' perceptions of college recruiting activities. Unpublished doctoral dissertation, University of Mississippi.

Xu, B. (1991). Marketing to China: One billion new customers. Chicago: NTC Business Books.

$\mathrm{Xu}, \mathrm{H}$. (1998). Third-rate colleges also have first rate students. Chinese Education and Society, 32(4), 6-9.

Yanshen, R. (1997, August 17). Report recognises the key role of education. China Daily, p 3. 